\title{
Using of essential oils in the treatment of mice infected with Trypanosoma evansi
}

\section{Uso de aceites esenciales en el tratamiento de ratones infectados con Trypanosoma evansi}

\author{
Matheus D Baldissera, ${ }^{1,2}$ Biomed, Aleksandro S Da Silva, ${ }^{3 *}$ Ph.D, Camila B Oliveira, ${ }^{1}$ Ph.D, \\ Rodrigo A Vaucher, ${ }^{2}$ Ph.D, Roberto CV Santos, ${ }^{2}$ Ph.D, Janice L Giongo, ${ }^{4}$ Ph.D, \\ Dianni M Capeleto, ${ }^{1}$ M.Sc, Alexandre A Tonin, ${ }^{1}$ Ph.D, Silvia G Monteiro, ${ }^{1}$ Ph.D.
}

\begin{abstract}
${ }^{1}$ Universidade Federal de Santa María (UFSM), Departamento de Microbiología y Parasitología, Avenida Roraima, 1000 - Camobi, Santa Maria - RS, 97105-900, Brasil. ${ }^{2}$ Centro Universitário Franciscano (UNIFRA), SRua dos Andradas, 1614 - Centro, Santa Maria - RS, 97010-032, Brasil. 3Universidade do Estado de Santa Catarina (UDESC), Departamento de Zootecnia, Avenida Madre Benvenuta, 2007 - Itacorubi, Florianópolis SC, 88035-001, Brasil. ${ }^{4}$ Universidade Regional Integrada do Alto do Uruguai (URI), Laboratorio de Tecnología Farmacéutica, Centro de Ciências da Saúde, Avenida Batista Bonoto Sobrinho, 733 - Santiago/RS - 97700-000, Brasil. *Correspondencia: aleksandro_ss@yahoo.com.br
\end{abstract}

Received: October 2013; Accepted:January 2014.

\begin{abstract}
Objective. This study aimed to test the effectiveness of copaiba, andiroba and aroeira essential oils for controlling trypanosomosis by Trypanosoma evansi with mice as experimental model. Materials and methods. Sixty-six mice were divided into eleven groups ( $A$ to $L$ ) with six animals each. Group $A$ was the unique composed by healthy and uninfected animals (negative control). Animals in groups $B$ to $L$ were inoculated with $0.1 \mathrm{~mL}$ of blood containing $2.7 \times 10^{6}$ trypanosomes. Group B was used as a positive control without treatment. In experiment were tested copaiba ( $C, D$ and $E)$, andiroba $(F, G$ and $\mathrm{H}$ ) and aroeira ( $\mathrm{I}, \mathrm{J}$ and $\mathrm{L}$ ) oils at doses of $0.6,0.8$ and $1.0 \mathrm{~mL} \mathrm{~kg}^{-1}$ to infected mice ( $T$. evansi). Results. These protocols did not provide curative efficacy; however, the mice treated with highest dose of copaiba showed a significant increase in the longevity when compared others groups. Conclusions. Previously in our studies, these essential oils have shown trypanocidal activity in vitro, but when they were tested in vivo in mice infected with $T$. evansi, this trypanocidal activity, or the curative effect was not found, being only able to prolong the lifespan of the animals treated with copaiba oil.
\end{abstract}

Key words: Copaiba, in vitro, longevidad, mice, oils (Source: $C A B, M e S H$ ).

\section{RESUMEN}

Objetivo. Este estudio tuvo como objetivo evaluar la eficacia de los aceites esenciales de copaiba, andiroba y aroeira para controlar la tripanosomiasis por Trypanosoma evansi con ratones como modelo experimental. Materiales y métodos. Sesenta y seis ratones se dividieron en once grupos $(A$ a $L)$ con seis animales cada uno. Grupo A fue el único compuesto por los animales sanos y no infectadas (control negativo). Los animales en los grupos $B$ a L fueron inoculados con $0.1 \mathrm{~mL}$ de sangre que contiene $2.7 \times 10^{6}$ tripanosomas. Grupo B se utilizó como control positivo, sin tratamiento. En el 
experimento se pusieron a prueba los aceites de copaiba ( $C, D$ y E), andiroba $(F, G$ y H) y aroeira (I, J y $L$ ) en una dosis de $0.6,0.8$ y $1.0 \mathrm{ml} \mathrm{kg}^{-1}$ en ratones infectados ( $T$. evansi). Resultados. Estos protocolos no proporcionan una eficacia curativa; sin embargo, los ratones tratados con la dosis más alta de copaiba mostraron un aumento significativo en longevidad en comparación con otros grupos. Conclusiones. De forma previa en nuestros estudios, estos aceites esenciales han demostrado actividad tripanocida in vitro, pero cuando se ensayaron in vivo en ratones infectados con $T$. evansi, no se encontró esta actividad tripanocida o el efecto curativo, siendo sólo capaz de prolongar la vida de los animales tratados con aceite de copaiba.

Palabras clave: Aceites, copaiba, in vitro, longevity, ratones (Fuente: $C A B, M e S H$ ).

\section{INTRODUCTION}

The properties of some components present on medicinal plants have drawn the attention of the population and the scientific community (1). In this context, natural resources from the Amazon region generate interest to be used as herbal medicines, such as copaiba and andiroba oils (2). Another plant of the region of South America that has excelled results in research is aroeira $(3,4)$.

Copaiba oil is extracted from the trunk Copaifera spp., (Leguminosae) a common tree of in the Amazon rainforest (5). In folk medicine this oil resin is commonly used, because it has been described anti-inflammatory action (6), gastric protection, have healing effect (7), bactericidal (6) and phytopathogenic activity (8). The andiroba oil is extracted from a tree known as Carapa guianensis, which belongs to the Meliaceae family, found in several countries in South America (9). Its oil is used in folk medicine due to its properties, such as analgesic, antiinflammatory, antibacterial, antiparasitic and in therapy against various types of cancer (1013), besides having acaricide effect (9), as well as the larvicidal properties (14). The aroeira oil (Schinus molle L.), which has anti-inflammatory and antimicrobial properties, is extracted from a plant belonging to the family Anacardiciaceae, with several species distributed in southern Brazil $(3,4)$. In vitro trypanocidal activity of copaiba, andiroba and aroeira essential oils has been already confirmed in preliminaries studies $(15,16)$.

Trypanosoma evansi is a protozoan, the etiological agent of the disease known as "Mal das cadeiras" or "Surra" in horses (17). The treatment of trypanosomosis by $T$. evansi is based on antiprotozoal drugs such as suramine, diminazene aceturate, quinapyramine, melarsoprol and isometamidium (18). The diminazene aceturate is the most commonly drug used for controlling the trypanosomosis in domestic animals, since it presents a higher therapeutic index when compared to the other drugs used in this species, besides its lower cost (19). The greatest

\section{INTRODUCCIÓN}

Las propiedades de algunos componentes presentes en plantas medicinales han llamado la atención de la población y la comunidad científica (1). En este contexto, los recursos naturales de la región amazónica generan interés para ser utilizados como hierbas medicinales, como los aceites de copaiba y andiroba (2). Otra planta de la región de América del Sur que se ha destacado por sus resultados en investigaciones es la aroeira $(3,4)$.

El aceite de copaiba se extrae del tronco de Copaifera spp., (Leguminosae) un árbol común en la selva amazónica (5). En la medicina popular esta resina de aceite se utiliza comúnmente por sus efectos antiinflamatorios (6), protección gástrica, efectos curativos (7), bactericida (6) y actividad fitopatógenas (8). El aceite de andiroba se extrae de un árbol denominado Carapa guianensis, el cual pertenece a la familia Meliaceae y es encontrado en varios países de América del Sur (9). Su aceite es utilizado en la medicina popular debido a sus propiedades como analgésico, antiinflamatorio, antibacteriano, antiparasitario y como terapia en contra de varios tipos de cáncer (10-13), además de tener un efecto acaricida (9) así como propiedades larvicidas (14). El aceite de aroeira (Schinus molle L.), el cual posee propiedades antiinflamatorias y antimicrobianas, se extrae de una planta que pertenece a la familia Anacardiciaceae, con varias especies distribuidas en el sur de Brasil $(3,4)$. La actividad tripanocida in vitro de los aceites esenciales de copaiba, andiroba y aroeira ya ha sido confirmada en estudios preliminares $(15,16)$.

Trypanosoma evansi es un protozoo, el agente etiológico de la enfermedad conocida como "Mal das cadeiras" o "Surra" en caballos (17). El tratamiento de la tripanosomiasis por $T$. evansi se basa en fármacos antiprotozoarios como suramina, diaminazina aceturato, quinapiramina, melarsoprol e isometamidium (18). La diaminazina aceturato es el medicamento más comúnmente usado para controlar la 
difficulties faced in trypanosomosis therapy are the high toxicity and the emergence of resistant strains, mainly due to the fact that most of these compounds are used in the field therapy for more than forty years (17). It is clear the needs for researches focusing in new therapeutic options, and, therefore, the aim of this study was assess the effectiveness of copaiba, andiroba and aroeira essential oils on the trypanosomosis controlling, using as experimental model mice infected with Trypanosoma evansi.

\section{MATERIAL AND METHODS}

Study site. The experiment was conducted at Veterinary Parasitology Laboratory, at Santa Maria Federal University, in Santa Maria city, Brazil.

Evaluated oils. Andiroba oil (Carapa guianensis) RF3150 and copaiba oil (Copaifera officinalis) RF3350 were purchased from Beraca Sabará Chemical and Ingredients S/A (São Paulo, Brazil). The leaves of the species Schinus molle L. were collected in the biological reserve of the Universidade da Região da Campanha (URCAMP), Bagé/RS, and extracted in laboratory as previously described (16). This study was used an isolate of T. evansi (LPV-2005) (20) kept cryopreserved in liquid nitrogen in laboratory. During the first step one rats $\left(R_{1}\right)$ were inoculated intraperitoneally with infected blood by $T$. evansi to obtain a large amount of viable parasites for infection of experimental groups.

Experimental animal. Sixty-six mice (female), 70 days old and weighing an average of $24 \pm 0.4$ grams were used as the experimental model. They were kept in cages, six mice each, housed on a light/dark cycle of $12 \mathrm{~h}$, and in an experimental room with temperature and humidity controlled $\left(25^{\circ} \mathrm{C} ; 70 \%\right.$ respectively). They were fed with commercial ration and water ad libitum. All animals were submitted to a period of 10 days for adaptation.

Experimental design and treatments. The mice were divided into eleven groups ( $A$ to $L$ ) with six animals each. Group A was the unique composed by healthy and uninfected animals (negative control). Animals in groups $B$ to $L$ were inoculated intraperitoneally with $0.1 \mathrm{~mL}$ of blood from a rat $\left(R_{1}\right)$ containing $2.7 \times 10^{6}$ trypanosomes (on Day 0). Group B was used as a positive control without treatment, while mice of groups C, D and $E$ received treatment with copaiba oil in doses $0.6,0.8$ and $1.0 \mathrm{~mL} \mathrm{~kg}^{-1}$, respectively. Groups F, G and $\mathrm{H}$ were treated with andiroba oil at $0.6,0.8$ and $1.0 \mathrm{~mL} \mathrm{~kg}^{-1}$, tripanosomiasis en animales domésticos, ya que presenta un mayor índice terapéutico en comparación con otros fármacos utilizados en esta especie, además de tener un menor costo (19). Las mayores dificultades en la terapia contra la tripanosomiasis son la alta toxicidad y la aparición de cepas resistentes, debido principalmente al hecho de que la mayoría de estos compuestos ha sido utilizado en terapia de campo durante más de cuarenta años (17). Está claro que las necesidades de las investigaciones que se centran en nuevas opciones terapéuticas y, por lo tanto, el objetivo de este estudio, fue la evaluación de la efectividad de los aceites esenciales de copaiba, andiroba y aroeira en el control de la tripanosomiasis, utilizando ratones infectados con Trypanosoma evansi como modelo experimental.

\section{MATERIALES Y MÉTODOS}

Sitio de estudio. El experimento se realizó en el Laboratorio de Parasitología Veterinaria, en la Universidad Federal de Santa María en la ciudad de Santa María, Brasil.

Aceites evaluados. Se adquirió el aceite de andiroba (Carapa guianensis) RF3150 y el aceite copaiba (Copaifera officinalis) RF3350 de Beraca Sabará Chemical and Ingredients S/A (Sao Paulo, Brasil). Las hojas de la especie Schinus molle L. fueron recolectadas en la reserva biológica de la Universidade da Região da Campanha (URCAMP), Bagé/RS y se extrajeron en un laboratorio según se describió anteriormente (16). En este estudio se utilizó una cepa aislada de $T$. evansi (LPV-2005) (20) que fue criopreservada en nitrógeno líquido en el laboratorio. Durante el primer paso, las ratas $\left(R_{1}\right)$ fueron inoculados intraperitonealmente con sangre infectada con $T$. evansi para obtener una gran cantidad de parásitos viables para la infección de los grupos experimentales.

Animales experimentales. Sesenta y seis ratones (hembras) de 70 días de edad y con un peso promedio de $24 \pm 0.4$ gramos fueron utilizados como modelo experimental. Éstos se mantuvieron en jaulas, seis ratones en cada una, ubicados en un ciclo de luz/oscuridad de $12 \mathrm{~h}$ y en una habitación experimental con temperatura y humedad controladas $\left(25^{\circ} \mathrm{C}\right.$; $70 \%$ respectivamente). Fueron alimentados con alimento comercial y agua ad libitum. Todos los animales fueron sometidos a un período de adaptación de 10 días.

Diseño experimental y tratamientos. Los ratones fueron divididos en once grupos ( $\mathrm{A}$ a $\mathrm{L})$ con 
respectively. Additionally, Groups I, J and L received treatment with aroeira oil at $0.6,0.8$ and $1.0 \mathrm{~mL} \mathrm{~kg}$, respectively. Treatment with essential oils was done, in all groups, orally. Two hours after inoculation of trypomastigotes (Day 0) the treatment was initiated, being it kept during three days, with dose intervals of 24 hours.

Evaluation of the experimental animals. The mice were observed for up to 20 days; being the evolution of parasitemia and the effect of the treatment were daily monitored through blood smear. Each slide was prepared with fresh blood collected from the tail vein, stained by the panoptic method, and visualized at a magnification of $1000 \mathrm{x}$.

Efficacy of treatment was determined by the number of animals healed after infection with $T$. evansi. However, to assess the treatment effect of essential oils, prepatent period, longevity and mortality of mice was determined.

Statistical analysis. The results of the prepatency period and longevity were submitted to analysis of variance followed by Duncan test $(p<0.05)$.

Ethical approval. The Animal Welfare Committee of Federal University of Santa Maria approved the procedure, number 65/2012.

\section{RESULTS}

The positive control group (group B) had in average a prepatent period of 24 hours. Groups C, F, G, I and L had similar prepatent period, while no significant difference was observed between groups ( $p>0.05)$. Groups D, E, H and J had a prepatent period significantly higher $(p \leq 0.05)$ if compared to group B (Table 1).

The experiment lasted 20 days, which was considered as the period of longevity of group A. The longevity of the group $B$ was 5.3 days, similar period observed in groups $\mathrm{C}, \mathrm{D}, \mathrm{F}, \mathrm{G}, \mathrm{H}, \mathrm{I}, \mathrm{J}$ and $L$. In contrast, animals in group $E$ had a longevity of 16.1 days, statistically higher $(p<0.05)$ when compared with others groups (Table 1 ). However, treatment with different doses the oils of copaiba, andiroba and aroeira had no curative effect in our mice experimentally infected with $T$. evansi, not preventing mortality of all mice, which occurred due to the high parasitemia observed (more of 100 trypanosomes/field at 1000x magnification). seis animales en cada uno. El grupo A fue el único compuesto por animales sanos y no infectados (control negativo). Los animales en los grupos $\mathrm{B}$ a $L$ fueron inoculados intraperitonealmente con 0,1 $\mathrm{mL}$ de sangre de una rata $\left(R_{1}\right)$ que contenía 2,7 $\times 10^{6}$ tripanosomas (en el Día 0). El grupo B fue utilizado como control positivo sin tratamiento, mientras que los ratones de los grupos C, D y E recibieron tratamiento con aceite de copaiba en dosis de $0,6,0,8$ y $1,0 \mathrm{~mL} \mathrm{~kg}^{-1}$, respectivamente. Los grupos $\mathrm{F}, \mathrm{G}$ y $\mathrm{H}$ fueron tratados con aceite de andiroba en dosis de 0,6, 0,8 y $1,0 \mathrm{~mL} \mathrm{~kg}^{-1}$, respectivamente. Además, los grupos I, J y L recibieron tratamiento con aceite de aroeira en dosis de $0.6,0.8$ y $1.0 \mathrm{~mL} \mathrm{~kg}^{-1}$, respectivamente. El tratamiento con aceites esenciales se realizó por vía oral en todos los grupos. El tratamiento inició dos horas después de la inoculación de tripomastigotos (Día 0) y se mantuvo durante tres días, con intervalos de dosis de 24 horas.

Evaluación de los animales experimentales. Los ratones fueron observados durante 20 días; monitoreando diariamente la evolución de la parasitemia y el efecto del tratamiento a través de un frotis de sangre. Cada lámina fue preparada con sangre fresca recolectada de la vena de la cola, teñida mediante el método panóptico y visualizada con un aumento de 1000x.

La eficacia del tratamiento fue determinada por el número de animales curados después de la infección con $T$. evansi. Sin embargo, para evaluar el efecto del tratamiento con aceites esenciales, se determinó el período de prevalencia, la longevidad y mortalidad de los ratones.

Análisis estadístico. Los resultados del período de prevalencia y la longevidad se sometieron a un análisis de varianza seguido de la prueba de Duncan $(p<0.05)$.

Aprobación ética. El Comité de Bienestar Animal de la Universidad Federal de Santa María aprobó el procedimiento, número 65/2012.

\section{RESULTADOS}

El grupo de control positivo (grupo B) tenía en promedio un período de prevalencia de 24 horas. Los grupos C, F, G, I y $L$ presentaron un período de prevalencia similar mientras que no se observó ninguna diferencia significativa entre los grupos $(p>0.05)$. Los grupos $D, E, H$ y J presentaron un período de prevalencia significativamente mayor $(p \leq 0.05)$ si se compara con el grupo B (Tabla 1$)$. 
Table 1. Mean and standard deviation of the prepatent period, longevity and mortality using treatment with oil of copaiba, andiroba and aroeira in mice experimentally infected with T. evansi.

\begin{tabular}{|c|c|c|c|c|}
\hline Groups & Treatment $^{\#}$ & $\begin{array}{l}\text { Prepatent } \\
\text { period }\end{array}$ & $\begin{array}{c}\text { Longevity } \\
\text { (Day) }\end{array}$ & $\begin{array}{l}\text { Mortality } \\
\text { (n) }\end{array}$ \\
\hline A & Negative control & - & $\begin{array}{c}20.0^{a} \\
( \pm 0.0)\end{array}$ & $0 / 6$ \\
\hline B & Positive control & $\begin{array}{c}1.0^{c} \\
( \pm 0.0)\end{array}$ & $\begin{array}{c}5.3^{\mathrm{cd}} \\
( \pm 1.0)\end{array}$ & $6 / 6$ \\
\hline C & Copaiba oil $(0.6 \mathrm{~mL} / \mathrm{Kg})$ & $\begin{array}{c}1.5^{\mathrm{bc}} \\
( \pm 0.5)\end{array}$ & $\begin{array}{c}5.5^{\mathrm{cd}} \\
( \pm 2.2)\end{array}$ & $6 / 6$ \\
\hline $\mathrm{D}$ & Copaiba oil $(0.8 \mathrm{~mL} / \mathrm{Kg})$ & $\begin{array}{c}2.0^{\mathrm{ab}} \\
( \pm 1.6)\end{array}$ & $\begin{array}{c}7.0^{c} \\
( \pm 2.8)\end{array}$ & $6 / 6$ \\
\hline$E$ & Copaiba oil $(1.0 \mathrm{~mL} / \mathrm{Kg})$ & $\begin{array}{c}2.8^{\mathrm{ab}} \\
( \pm 0.9)\end{array}$ & $\begin{array}{c}16.1^{\mathrm{b}} \\
( \pm 4.8)\end{array}$ & $6 / 6$ \\
\hline $\mathrm{F}$ & Andiroba oil $(0.6$ mL/Kg) & $\begin{array}{l}1.3^{c} \\
( \pm 0.5)\end{array}$ & $\begin{array}{l}4.1^{\mathrm{d}} \\
( \pm 1.4)\end{array}$ & $6 / 6$ \\
\hline G & Andiroba oil $(0.8 \mathrm{~mL} / \mathrm{Kg})$ & $\begin{array}{c}1.0^{c} \\
( \pm 0.0)\end{array}$ & $\begin{array}{c}4.1^{\mathrm{d}} \\
( \pm 0.4)\end{array}$ & $6 / 6$ \\
\hline $\mathrm{H}$ & Andiroba oil $(1.0 \mathrm{~mL} / \mathrm{Kg})$ & $\begin{array}{c}2.6^{a} \\
( \pm 1.6)\end{array}$ & $\begin{array}{c}7.1^{c} \\
( \pm 3.8)\end{array}$ & $6 / 6$ \\
\hline I & Aroeira oil $(0.6 \mathrm{~mL} / \mathrm{Kg})$ & $\begin{array}{c}1.3^{c} \\
( \pm 0.5)\end{array}$ & $\begin{array}{c}4.8^{\text {cd }} \\
( \pm 0.8)\end{array}$ & $6 / 6$ \\
\hline J & Aroeira oil $(0.8 \mathrm{~mL} / \mathrm{Kg})$ & $\begin{array}{c}2.0^{\mathrm{ab}} \\
( \pm 0.7)\end{array}$ & $\begin{array}{c}7.0^{c} \\
( \pm 3.8)\end{array}$ & $6 / 6$ \\
\hline L & Aroeira oil $(1.0$ mL/Kg) & $\begin{array}{c}1.2^{c} \\
( \pm 0.4)\end{array}$ & $\begin{array}{l}6.5^{\mathrm{cd}} \\
( \pm 1.0)\end{array}$ & $6 / 6$ \\
\hline
\end{tabular}

Means followed by same letters in the same column do not differ significantly in the test of Duncan. ${ }^{~ E a c h ~ g r o u p ~ c o n s i s t e d ~ o f ~ s i x ~ m i c e . ~}$ The experiment lasted 20 until days post-infection, when the last two mice of the treated groups (group $\mathrm{E}$ and $\mathrm{H}$ ) died.

\section{DISCUSSION}

Our research group has been conducted studies with essential oils by, standing out the experiment where the trypanocidal activity in vitro of copaiba, andiroba and aroeira oils was detected (16). Especially due to these findings, this study was proposed to assess the activity in vivo of these oils on mice infected with $T$. evansi. Therefore, was evaluated the susceptibility in vivo of $T$. evansi to oils of copaiba, andiroba and aroeira in three different concentrations. As a result, was observed that the oils tested were not effective in the treatment of infection by $T$. evansi in mice at the doses administered, since all animals infected and treated died. However, some mice showed higher pre-patent period when compared to the positive control group, demonstrating an initial trypanocidal activity, but not a long-term curative.

Study showed that animals infected with Leishmania amazonensis and treated orally with the copaiba oil showed a significant reduction in the size of lesions (21). However, when investigators used a similar treatment to mice infected with $T$. evansi not succeeded because the animals died (22). In the current study, the dose of $1 \mathrm{~mL} \mathrm{~kg}^{-1}$ prolonged the lives of animals, being a natural product with therapeutic potential for this disease.
El experimento duró 20 días, el cual se considera como el período de longevidad del grupo $A$. La longevidad del grupo B fue de 5,3 días; se observó un período similar en los grupos C, D, F, G, H, I, J y L. En contraste, los animales del grupo E tuvieron una longevidad de 16,1 días, lo que resulta estadísticamente superior $(p<0.05)$ en comparación con los otros grupos (Tabla 1 ). Sin embargo, el tratamiento con diferentes dosis de los aceites de copaiba, andiroba y aroeira no tuvo ningún efecto curativo en los ratones infectados experimentalmente con $T$. evansi, sin prevenir la mortalidad de los ratones, lo que se produjo debido a la alta parasitemia observada (más de 100 tripanosomas/campo con un aumento de 1000x).

\section{DISCUSIÓN}

Nuestro grupo de investigación ha realizado estudios realizados con aceites esenciales, destacándose el experimento donde la actividad tripanocida in vitro de los aceites de copaiba, andiroba y aroeira fue detectada (16). Debido especialmente a estos resultados, en este estudio se propuso evaluar la actividad in vivo de estos aceites en ratones infectados con $T$. evansi. Por lo tanto, se evaluó la susceptibilidad in vivo de $T$. evansi a los aceites de copaiba, andiroba y aroeira en tres concentraciones diferentes. Como resultado, se observó que los aceites probados no eran efectivos en el tratamiento de la infección por $T$. evansi en ratones en las dosis administradas, dado que todos los animales infectados y tratados fallecieron. Sin embargo, algunos ratones mostraron un mayor período de prevalencia en comparación con el grupo control positivo, mostrando una actividad tripanocida inicial pero no un curativo a largo plazo.

El estudio demostró que los animales infectaron con Leishmania amazonensis y tratados por vía oral con el aceite de copaiba mostraron una reducción significativa en el tamaño de las lesiones (21). No obstante, cuando los investigadores utilizaron un tratamiento similar en ratones infectados con $T$. evansi no tuvieron éxito porque los animales murieron (22). En el presente estudio, la dosis de $1 \mathrm{~mL} \mathrm{~kg}^{-1}$ prolonga la vida de los animales, al ser un producto natural con un potencial terapéutico para esta enfermedad.

Los estudios in vitro realizados por investigadores demostraron la actividad tripanocida de los compuestos presentes en las plantas del género Copaifera spp., es decir el ácido copalico y $\beta$-cariofileno poseen un efecto sinérgico contra cepas de Trypanosoma cruzi en una 
In vitro, studies conducted by researchers demonstrated the trypanocidal activity of compounds present in plants of the genus Copaifera spp., i.e., the copalic acid and $\beta$-caryophyllene had synergistic effect against strains of Trypanosoma cruzi in a concentration of $12 \mu \mathrm{g} \mathrm{mL}^{-1}(23)$. In the same study, it was also found that kaurenoic and polylactic acid inhibited the proliferation of the parasite in the concentration of $50 \mu \mathrm{g} \mathrm{mL}$. However, even then the terpernes are compounds present in copaiba oil, and presented different mechanisms known to cause death of trypanosomes, as well as oxidative stress, autophagy and osmotic pressure difference (23). Since in our experiment the infection with $T$. evansi in mice was acute, probably the oil, or its properties, did not have enough time to perform the complete cleaning of the parasite, as it multiplies very fast; allowing only an increase in life time of the animals, as it was possible to observe in study current.

Previous results of our research group demonstrated that some essential oils showed significant trypanocidal activity on $T$. evansi, when in vitro conditions. However, in this research, was found that essential oils of andiroba, copaiba and aroeira were not effective in the treatment of mice experimentally infected by $T$. evansi, only presenting a slight control of parasitism in the early course of the infection.

\section{Acknowledgments}

This work was supported by Fundação de Amparo a Pesquisa do Estado do Rio Grande do Sul (FAPERGS, RS, Brazil), and the Universidade Federal de Santa Maria (RS, Brazil). concentración de $12 \mu \mathrm{g} \mathrm{mL}^{-1}$ (23). En el mismo estudio se encontró también que el ácido caproico y poliláctico inhibió la proliferación del parásito en un concentración de $50 \mu \mathrm{g} \mathrm{mL}^{-1}$. Sin embargo, incluso así los terpernos son compuestos presentes en el aceite de copaiba y presentaron diferentes mecanismos que se conoce causan la muerte de los tripanosomas, así como estrés oxidativo, autofagia y diferencia de presión osmótica (23). Puesto que en nuestro experimento la infección con $T$. evansi en ratones fue aguda, probablemente el aceite, o sus propiedades, no tuvo tiempo suficiente para realizar una limpieza completa del parásito, ya que éste se multiplica muy rápidamente; permitiendo únicamente un aumento en el tiempo de vida de los animales, como fue posible observar en este estudio.

Los resultados previos de nuestro grupo de investigación demostraron que algunos aceites esenciales mostraron una actividad tripanocida significativa en $T$. evansi bajo condiciones in vitro. Sin embargo, en esta investigación se encontró que los aceites esenciales de andiroba, copaiba y aroeira no fueron efectivos en el tratamiento de ratones infectados experimentalmente con $T$. evansi, presentando únicamente un leve control del parasitismo en el curso temprano de la infección.

\section{Agradecimientos}

Este trabajo fue apoyado por Fundação de Amparo a Pesquisa do Estado Rio Grande do Sul (FAPERGS, RS, Brasil) y la Universidade Federal de Santa María (RS, Brasil).

\section{REFERENCES}

1. Pinto AC, Silva DHS, Bolzani VS, Lopes NP, Epifanio RA. Produtos naturais: atualidade, desafios e perspectivas. Químíca Nova 2002; 25:45-61.

2. Maciel MAM, Pinto AC, Júnior VF. Plantas medicinais: A necessidade de estudos interdisciplinares. Química Nova 2002; 25: 429-438.

3. Amorim MMR, Santos LC. Tratamento da vaginose bacteriana com gel vaginal de Aroeira (Schinus terebinthifolius Raddi): ensaio clínico randomizado. Rev Bras Ginecol Obstet 2003; 25:95-102.
4. Marongiu B, Alessandra PSP, Casu R, Pierucci P. Chemical composition of the oil and supercritical $\mathrm{CO}_{2}$ extracts of Schinus molle L. Flav Frag J 2004; 19:554-558.

5. Araújo Jr FA, Braz MN, Neto OGR, Costa FD, Brito MVH. Efeito do óleo de copaíba nas aminotransferases de ratos submetidos à isquemia e reperfusão hepática com e sem précondicionamento isquêmico. Acta Cir Bras 2005; 20:93-99.

6. Veiga VF, Patitucci ML, Pinto AC. Authenticity control of commercial copaiba oils by high resolution gas chromatography. Química Nova 1997; 20:612-615. 
7. Paiva LAF, Gurgel LA, Silva RM, Tomé AR, Gramosa NV, Silveira ER, Santos FA, Rao VNS. Anti-inflammatory effect of kaurenoic acid, a diterpene from copaifera langsdorffi on acetic acid-induced colitis in rats. Vascular Pharmacol 2002; 39:303-307.

8. Oliveira ECP de, Lameira OA, Barros PLC, Poltronieri LS. Avaliação do óleo de copaíba (Copaifera) na inibição do crescimento micelial in vitro de fitopatógenos. Rev Ciênc Agr 2006; 46:53-61.

9. Farias MPO, Sousa DP, Arruda AC, Arruda MSP, Wanderley AG, Alves LC, Faustino MAG. Eficácia in vitro do óleo da Carapa guianensis Aubl. (Andiroba) no controle de Boophilus microplus (Acari: Ixodidae). Rev Bras Plan Med 2007; 9:68-71.

10. Gilbert B, Teixeira DF, Carvalho ES, De Paula AE, Pereira JF, Almeida MB, Machado RS, Cascon V. Activities of the pharmaceutical technology Institute of the Oswaldo Cruz Fundation with medicinal, insecticidal and repellent plants. Anais Acad Bras Ciênc 1999; 71:265-271.

11. Moura MD, Souza - Silva J, De Oliveira RAG, Diniz MFFM, Barbosa - Filho JM. Natural products reported as potencial inibitors of uterine cervical neoplasia. Acta Farmac Bonar 2002; 21:67-74.

12. Penido C, Costa KA, Costa MF, Pereira JF, Siani $A C$, Henriques MG. Inhibition of allergen induced eosinophil recruitment by natural tetranortriterpenoids is mediated by the suppression of IL-5, CCL11/eotaxin and Nfkappa ${ }^{\mathrm{B}}$ activation. Int Immunopharmacol 2006; 6:109121.

13. Santos RBC, Dos Santos Alves CF, Schneider T, Lopes LQ, Aurich C, Giongo JL, Brandelli A, Vaucher RA. Antimicrobial activity of Amazonian oils against Paenibacillus species. J Inve Pathol 2012; 109:265-268.

14. Mendonça FA, Silva KF, Santos KK, Ribeiro Júnior KA, Sant'ana AE. Activities of some Brazilian plants against larvae of the mosquito Aedes aegypti. Fitorerapia 2005; 76:629-636.
15. Izumi E. Efeitos do óleo de copaíba e constituintes em Trypanosoma cruzi, 95f. Londrina, PR. [Tese Doutorado em Microbiologia] - Programa de Pós- graduação em Microbiologia, Universidade Federal de Londrina, 2010.

16. Baldissera MD, Da Silva AS, Oliveira $C B$, Zimmermann CEP, Vaucher RA, Santos RCV, Rech VC, Tonin AA, Giongo JL, Mattos CB, Koester L, Santurio JM, Monteiro SG. Trypanocidal activity of the essential oils in their conventional and nanoemulsion forms: In vitro tests. Exp Parasitol 2013; 134:156-161.

17. Silva RAMS, Seidl A, Ramirez L, Dávila AMR. Trypanosoma evansi e Trypanosoma vivax: biologia, diagnóstico e controle. Corumbá, Brasil: Embrapa Pantanal; 2002.

18. Maudlin I, Holmes $P$, Miles MA. The trypanosomiases. Wallingford, Inglaterra: CABI Publishing; 2004.

19. Peregrine AS, Mamman M. Pharmacology of Diminazene: A Review. Acta Tropica 1993; 54:185-203.

20. Colpo CB, Colpo ETB, Stainki DR, Monteiro SG. Infecção Natural por Trypanosoma evansi em cão no Rio Grande do Sul. Ciência Rural 2005; 35:717-719.

21. Santos AO, Ueda-Nakamura T, Dias Filho BP, Veiga Junior VFV, Lima MMS, Nakamura CV. Leishmania amazonensis: Effects of oral treatment with copaiba oil in mice. Exp Parasitol $2011 ; 129: 154-151$.

22. Dornelles F, Da Silva AS, Oliveira CB, Dalla-Rosa L, Zimmermann CEP, Tonin AA, Oliveira ECP, Santurio, JM, Monteiro SG. Susceptibility of Trypanosoma evansi in the copaiba oil: In vitro test and in mice experimentally infected with the parasite. Acta Scie Vet 2013; 41:1136.

23. Izumi E, Ueda - Kakamura T, Veiga Júnior VF, Pinto AC, Nakamura CV. Terpenes from Copaifera demonstrated in vitro antiparasitic and synergic activity. J Med Chem 2012; 55:2994-3001. 